\section{Bagging Chopped Lettuce in Selected Permeability Films}

Roy E. McDonald and Lawrence A. Risse

Agricultural Research Service, U.S. Department of Agriculture, 2120

Camden Road, Orlando, FL 32803

\author{
Charles R. Barmore \\ Cryovac Division, W. R. Grace \& Company, P. O. Box 464, Duncan, \\ SC 29344-0464
}

Additional index words. Lactuca sativa, modified atmosphere film bags, shelf life, storage, quality, appearance, flavor

\begin{abstract}
Chopped 'Salinas' crisphead lettuce (Lactuca sativa L.) was packaged in four types of polymeric films and stored at 1 or $5 \mathrm{C}$ for 14 days. Discoloration and off-flavors developed in lettuce stored in the two films in which the naturally produced $\mathrm{CO}_{2}$ rose above $20 \%$. In the two films (oriented low-density polyethylene) with $\mathrm{O}_{2}$ transmission rates higher than $3000 \mathrm{ml} \cdot \mathrm{m}^{-2} \cdot \mathrm{day}^{-1} \cdot \mathrm{atm}^{-1}$ at $22 \mathrm{C}$, $\mathrm{CO}_{2}$ remained below $20 \%, \mathrm{O}_{2}$ was between $\approx 2 \%$ and $15 \%$, and the lettuce was acceptable after 14 days of storage at either 1 or 5C. Appearance and flavor were affected more by temperature than by length of storage.
\end{abstract}

There is a growing demand for prepackaged chopped and shredded lettuce for use in restaurants, institutions, supermarket salad bars, and consumer packs for home use. The popularity of the product stems from the convenience of having to do no washing, trimming, and cutting. However, the precut product has a relatively short shelf life, in part because of the large amount of tissue damage resulting from the cutting into saladsize pieces. Such damage results in increased respiration and transpiration and, additionally, may lead to increased microbial degradation (Priepke et al., 1976).

Polymeric films have been developed that will allow produce to establish a modified atmosphere through respiration. The equilibrium gas concentrations thus developed within the package may extend the shelf life of the product. Modified atmosphere (MA) effects on biochemical and physiological factors are commodity specific. Research on uncut crisphead lettuce has shown that the effects of MA are highly temperature- (Brecht et al., 1973a) and cultivar-dependent (Brecht et al., 1973b). MA for cut salad lettuce has been researched much less. Krahn (1977) found temperature to be the single most important variable in the storage of bagged lettuce and reported that the best quality was achieved with a polypropylene film, in which a self-generated $\mathrm{MA}$ of $9 \% \mathrm{CO}_{2}$ and $11 \%$

Received for publication 7 Aug. 1989. Mention of a trademark, warranty, proprietary product, or vendor does not constitute a guarantee by the USDA and does not imply its approval to the exclusion of other products or vendors that may also be suitable. We gratefully acknowledge Edith Garrett of South Bay Growers, South Bay, Fla., for supplying the lettuce and Roxanne Wiseman for technical assistance in this work. The cost of publishing this paper was defrayed in part by the payment of page charges. Under postal regulations, this paper therefore must be hereby marked advertisement solely to indicate this fact.
$\mathrm{O}_{2}$ was attained at $0 \mathrm{C}$ in 2 weeks. Ballantine et-al. (1988) reported that the least browning and absence of off-odors for shredded lettuce resulted from using a low-density polyethylene film with an equilibrated MA of 5\% bars represent $95 \%$ confidence levels for the mean. to $6 \% \mathrm{CO}_{2}$ and $1 \%$ to $3 \% \mathrm{O}_{2}$ at $5 \mathrm{C}$.

Development of off-flavors is a potential drawback of MA storage. At very low $\mathrm{O}_{2}$ concentrations ( $<1 \%$ ), off-flavor development caused by fermentation reactions can take place (Brecht, 1980). Elevated $\mathrm{CO}_{2}$ levels $(>10 \%)$ likewise have been shown to produce off-flavors in broccoli (Lipton and Harris, 1974). Therefore, a MA treatment used to extend the shelf life of a commodity should include an evaluation of quality. Our study evaluates the effect of four films with diverse gas transmission rates on the extension of shelf life and quality of chopped 'Salinas' lettuce.

'Salinas' crisphead lettuce was harvested, field-packed, vacuum-cooled to 2 to $3 \mathrm{C}$, and transported by truck (thermostat setting 2C) from Salinas, Calif., to South Bay Growers, South Bay, Fla. Five days elapsed from the time of harvest to arrival in Florida. The day following arrival, the lettuce was cored, trimmed, chopped $\left(\approx 2.5 \mathrm{~cm}^{2}\right)$, washed with chlorinated water $\left(20 \mu \mathrm{l} \cdot\right.$ liter $\left.^{-1}\right)$ at $2 \mathrm{C}$, and dried by a mechanical water separator and centrifugal dryer before being packaged in polymeric film bags. These operations were carried out below 7C. About $1.8 \mathrm{~kg}$ of lettuce were packaged in bags made from one of four films (Table 1). Each bag had a total surface area of $\approx 0.18 \mathrm{~m}^{2}$. Oxygen trans-
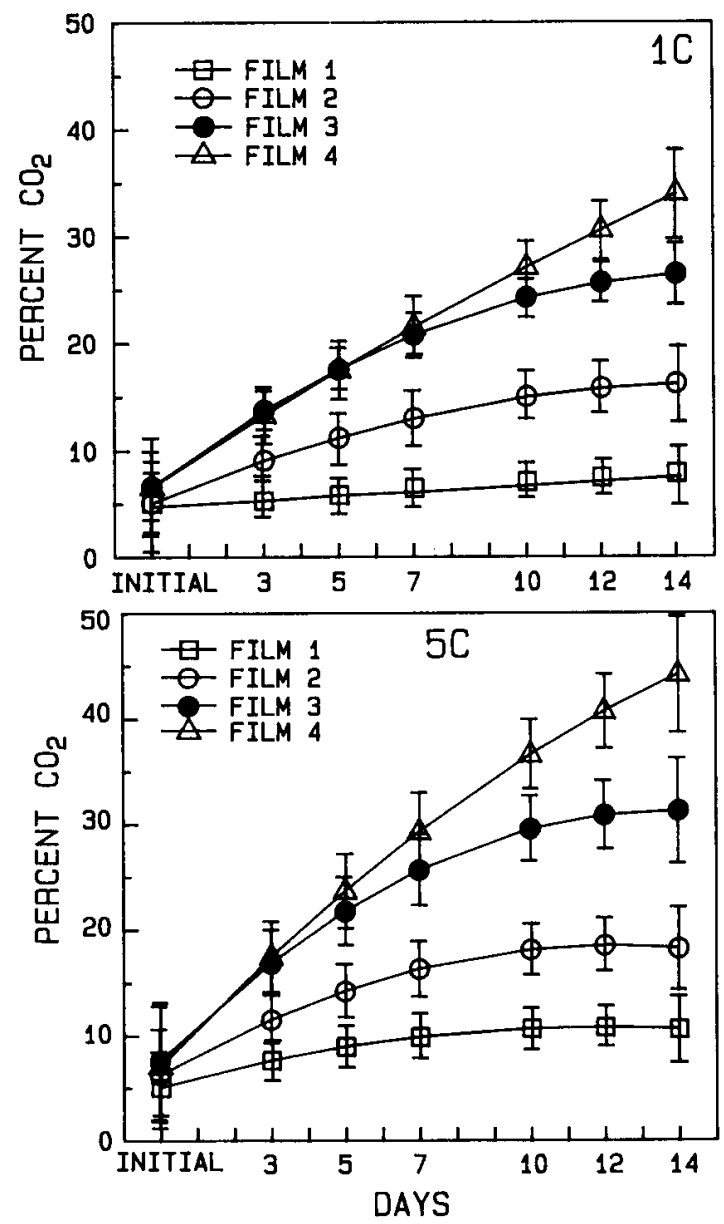

Fig. 1. Carbon dioxide levels in four types of sealed packages of polymeric films (see Table 1 for details) filled with chopped crisphead lettuce stored at 1 or $5 \mathrm{C} \pm 0.5 \mathrm{C}$ and $85 \% \pm 5 \% \mathrm{RH}$. Vertical 

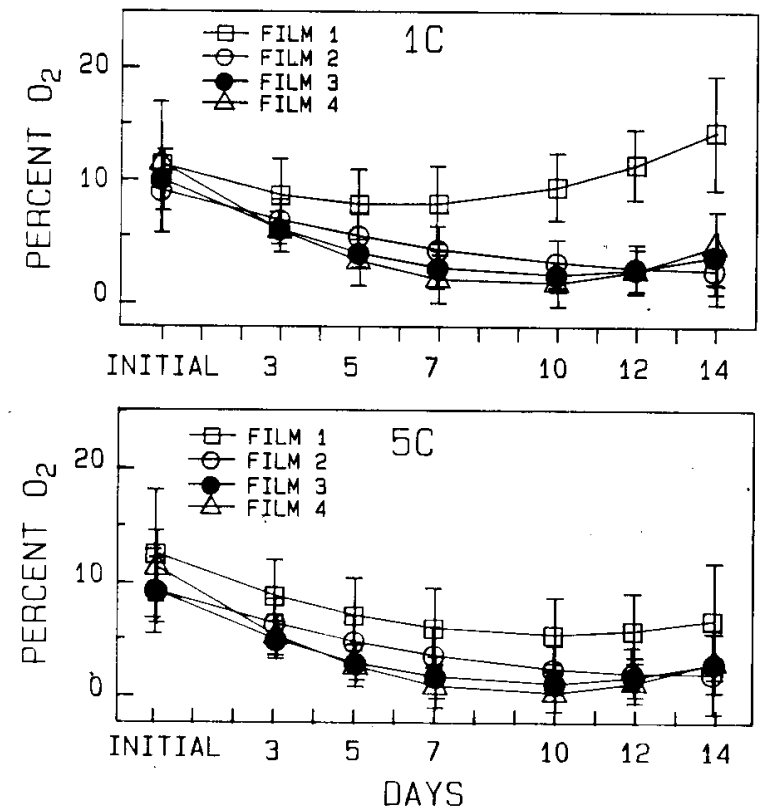

Fig. 2. Oxygen levels in four types of sealed packages of polymeric films (see Table 1 for details) filled with chopped crisphead lettuce stored at 1 or $5 \mathrm{C} \pm 0.5 \mathrm{C}$ and $85 \% \pm 5 \% \mathrm{RH}$. Vertical bars represent $95 \%$ confidence levels, for the mean.

Table 1. Properties of polymeric films used to bag chopped lettuce.

\begin{tabular}{|c|c|c|}
\hline Designation & $\begin{array}{l}\mathrm{O}_{2} \text { transmission rate at } 22 \mathrm{C} \\
\left(\mathrm{ml} \cdot \mathrm{m}^{-2} \cdot \text { day }^{-1} \cdot \mathrm{atm}^{-1}\right)\end{array}$ & Film \\
\hline 1 & 8000 & $\begin{array}{l}25-\mu \mathrm{m} \text { multilayer oriented linear } \\
\text { low-density polyethylene }\end{array}$ \\
\hline 2 & 3000 & $\begin{array}{l}63-\mu \mathrm{m} \text { multilayer oriented linear } \\
\text { low-density polyethylene }\end{array}$ \\
\hline 3 & 1700 & $\begin{array}{l}\text { 17- } \mu \mathrm{m} \text { polypropylene }+50-\mu \mathrm{m} \text { linear } \\
\text { low-density polyethylene }\end{array}$ \\
\hline 4 & 150 & $\begin{array}{l}17-\mu \mathrm{m} \text { polyethylene terephthlate }+ \\
50-\mu \mathrm{m} \text { low-density polyethylene }\end{array}$ \\
\hline
\end{tabular}

Table 2. Sensory evaluation of chopped crisphead lettuce packaged in four types of polymeric films and stored at 1 and $5 \mathrm{C}^{\mathrm{z}}$

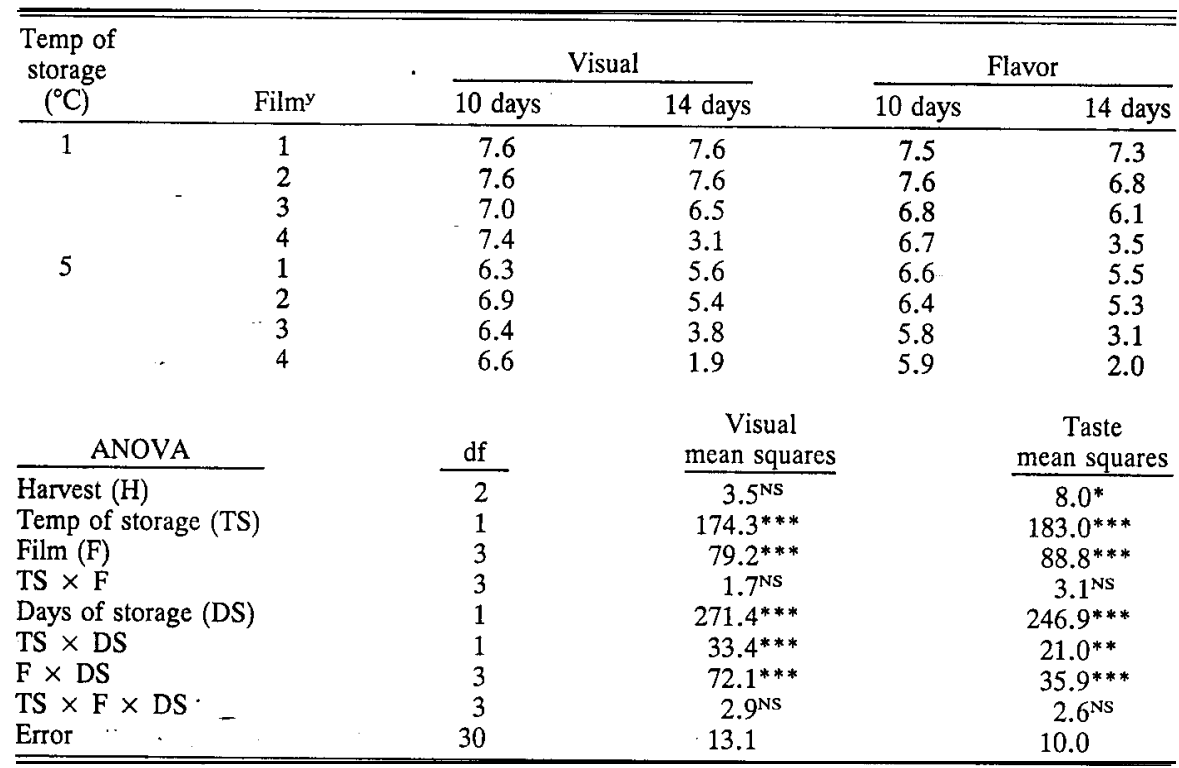

${ }^{2}$ Storage rooms maintained at temperature $\pm 0.5 \mathrm{C}$ and $85 \% \pm 5 \% \mathrm{RH}$.

${ }^{\text {y }}$ Refer to Table 1 for description of films.

Ns $, * *, * * *$ Nonsignificant or significant at $P=0.05,0.01$, or 0.001 , respectively.

mission rates are commonly used to describe films and they are about one third to one fifth of the $\mathrm{CO}_{2}$ transmission rates. Consequently, we used $\mathrm{O}_{2}$ transmission rates.

Film bags 1 and 2 (8000 and 3000 $\mathrm{ml} \cdot \mathrm{m}^{-2} \cdot$ day $^{-1} \cdot \mathrm{atm}^{-1}$, respectively) were filled with chopped lettuce, evacuated, and sealed at $\approx 27 \mathrm{~Pa}$ with a vacuum sealer (CVP Systems, Downers Grove, Ill.). In film bags 3 and $4\left(1700\right.$ and $150 \mathrm{ml} \cdot \mathrm{m}^{-2} \cdot \mathrm{day}^{-1} \cdot \mathrm{atm}^{-1}$, respectively), the air was excluded by means of pressure pads and the bags were sealed on a vertical form-fill and seal machine (General Packaging Equipment Co., Houston). The bagged lettuce was transported the same day in insulated ice chests to the U.S. Horticultural Research Laboratory in Orlando, Fla. Ten packages of each film type were placed in storage at 1 or $5 \mathrm{C} \pm 0.5 \mathrm{C}$ and $85 \% \pm 5 \%$ RH. Gas samples were taken at time of storage and after $3,5,7,10,12$, and 14 days by piercing the test film with a hypodermic needle and withdrawing $1.0 \mathrm{ml}^{3}$ with a syringe. Individual packages were pierced only once for gas sampling. If a package showed signs of leakage $\left(\mathrm{O}_{2}\right.$ levels $>16 \%$ to $18 \%$ ), it was not used for gas analysis or for sensory evaluation. Storage tests were replicated three times. A Hewlett Packard Model 5880 gas chromatography equipped with a thermal conductivity detector was used to measure the concentrations of $\mathrm{O}_{2}$ and $\mathrm{CO}_{2}$. Percentage composition was calculated with the aid of external standards of reference gas mixtures.

Two replicate packages each that had not been used for gas analysis were sampled after 10 and 14 days of storage for sensory evaluations by seven trained panel members (Kader et al., 1973). The lettuce was evaluated $30 \mathrm{~min}$ after the bags had been opened. Visual quality ratings were on a scale of 1 to 9 , where $9=$ excellent (free from defects) and 1 = extremely poor (not usable) (Kader et al., 1973). The rating scale for flavor was analogous. Sensory evaluation data were analyzed as a randomized complete-block design with factorial treatments (4 films $\times$ 2 temperatures $\times 2$ inspections) with three harvest dates (blocks) using the analysis of variance (ANOVA) procedure (SAS Institute, 1985).

Lettuce in films 1 and 2 was acceptable in appearance when stored for 14 days at either 1 or 5C (Table 2). However, film 4 rendered the lettuce poor in appearance after 14 days of storage at 1 and $5 \mathrm{C}$. The sensory panel described the appearance of the lettuce stored in film 4 as wilted and discolored ("fermented silage"). The appearance of the lettuce was affected more by temperature than by length of storage in films 1 and 2 vs. films 3 and 4 .

The patterns of flavor quality decline corresponded to those of appearance. Lettuce was affected more by storage temperature than by the length of storage, with the exception of that in film 4. Flavor of lettuce in film 4 was not acceptable after 14 days of storage at either 1 or $5 \mathrm{C}$ and lettuce flavor in film 3 was not acceptable after 14 days of storage at $5 \mathrm{C}$. Lettuce in these films was described by the panel as having a fermented flavor and an off-odor indicative of anaerobic respiration. Lettuce in films 1 and 2 still had an acceptable flavor after 14 days of storage at either 1 or $5 \mathrm{C}$.

To evaluate the effects of the four films 
in 1 and $5 \mathrm{C}$ storage, the accumulation of $\mathrm{CO}_{2}$ and depletion of $\mathrm{O}_{2}$ were determined as a percentage of total headspace gas (Figs. 1 and 2). The effects of reduced $\mathrm{O}_{2}$ and elevated $\mathrm{CO}_{2}$ on respiration are additive and can be greater than the effects of either alone (Zagory and Kader, 1988). Carbon dioxide accumulation averaged $\approx 24 \%$ higher for the four films at SC than at $1 \mathrm{C}$. In films 1 and 2 , those with higher gas transmission rates, gas composition was approaching equilibrium after 7 days of storage at both temperatures. Equilibrium was beginning to be reached in film 3 in $\approx 14$ days; however, it was not reached in film 4 even then, i.e., $\mathrm{CO}_{2}$ levels continued to increase during storage at both temperatures.

Oxygen levels in film 1, the one with the highest gas transmission rate, were generally higher than in the rest throughout storage at both temperatures. Oxygen levels ranged between $1 \%$ and $4 \%$ in films 2,3 , and 4 after 7 days of storage at either temperature (Fig. 2).

Our results indicate that film gas transmission rate and storage temperature are important in extending the shelf life of chopped lettuce, agreeing with those of others (Bolin et al., 1977; Krahn, 1977). Chopped lettuce stored at $5 \mathrm{C}$ had a significantly shorter shelf life, determined by appearance and flavor evaluations, than lettuce held at 1C. Although discoloration occurred and fermentation odors could be detected by the sensory panel when $\mathrm{CO}_{2}$ levels rose above $20 \%$ (films 3 and 4), no discoloration or fermentation was reported when $\mathrm{CO}_{2}$ was $<20 \%$ (films 1 and 2). Besides the discoloration of lettuce noticed in film 4 after 14 days, browning and discoloration of lettuce was seen in all bags when there was air leakage due to poor seals. Elevated $\mathrm{O}_{2}$ levels in these latter packages presumably accounted for the browning and discoloration. We conclude that films with $0_{2}$ transmission rates $>3000 \mathrm{ml} \cdot \mathrm{m}^{-2} \cdot \mathrm{day}^{-1} \cdot \mathrm{atm}^{-1}$ at $22 \mathrm{C}$ are required to extend the shelf life of 'Salinas' chopped lettuce when held at 1 to SC.

\section{Literature Cited}

Ballantine, A., R. Stark, and J.D. Selman. 1988 Modified atmosphere packaging of shredded lettuce. Intl. J. Food Sci. Technol. 23:267-274.

Bolin, H. R., A.E. Stafford, A.D. King, Jr., and C.C. Huxsoll. 1977. Factors affecting the storage stability of shredded lettuce. J. Food Sci. 42:1319-1321.

Brecht, P.E. 1980. Use of controlled atmospheres to retard deterioration of produce. Food Technol. 34:45-50.

Brecht, P.E., A.A. Kader, and L.L. Morris. 1973a. Influence of post-harvest temperature on brown stain of lettuce. J. Amer. Soc. Hort. Sci. 98:399402.

Brecht,, P. E., L.L. Morris, C. Cheyney, and D. Janecke. 1973b. Brown stain susceptibility of selected lettuce cultivars under controlled atmospheres and temperatures. J. Amer. Soc. Hort. Sci. 98:261-264.

Kader, A.A., W.J. Lipton, and L.L. Morris. 1973. Systems for scoring quality of harvested lettuce. HortScience 8:408-409.

Krahn, T.R. 1977. Improving the keeping quality of cut head lettuce. Acta Hort. 62:79-92.
Lipton, W.J. and C.M. Harris. 1974. Controlled atmosphere effects on the market quality of stored broccoli (Brassica oleracea L., Italica group). J. Amer. Soc. Hort. Sci. 99:200-205.

Priepke, P. E., L.S. Wei, and A.I. Nelson. 1976. Refrigerated storage of prepackaged salad veg- etables. J. Food Sci. 41:379-382.

SAS Institute, Inc. 1985. SAS user's guide: Statistics. SAS Inst., Cary, N.C.

Zagory, D. and A.A. Kader. 1988. Modified atmosphere packaging of fresh produce. Food Technol. 42:70-74, 76-77.

HORTSCIENCE 25(6):673-674. 1990.

\title{
Latex Colorant Slows Drying of Redcedar Christmas Trees
}

\author{
L.E. Hinesley ${ }^{1}$ \\ Department of Horticultural Science, North Carolina State University, \\ Raleigh, NC 27695-7609
}

Additional index words. Juniperus viriniana, xylem water potential

Abstract. Harvested eastern redcedar (Juniperus virginiana L.) Christmas trees coated with combinations of latex-based green colorant and needle sticker were observed for 2 weeks at $20 \mathrm{C}$. Green colorant reduced drying rates and helped maintain a better water status following dehydration. Even though these materials improve postharvest water relations, their primary value with respect to marketing and use of eastern redcedar Christmas trees is to impart a better color and/or mask the prickliness of juvenile foliage.

In recent years, latex-based green colorants have been used extensively by Christmas tree producers to enhance tree appearance during the fall harvest season. Many Christmas tree species, particularly pines, become yellow-green in late fall. Colorants, similar to thin latex paint, prevent or mask this effect if applied before the change. Despite the positive effect on tree appearance, the notion that colorants and needle stickers prolong shelf life of cut Christmas trees has not been well tested. Recent work with Douglas-fir [Pseudotsuga mensiesii (Mirb.) France] indicated that antitranspirants and colorants, when used under moderate to strong drying conditions, did little to retard drying unless applied at levels sufficiently high to render the tree qualitatively less acceptable to consumers (Montano and Proebsting, 1986).

Eastern redcedar is indigenous to most of the eastern United States and is important as a Christmas tree, particularly at the local level and in choose-and-cut operations. It is naturally light green to purplish-green in late fall. Colorants are routinely used to make trees dark green. A disadvantage of redcedar is that it dries very rapidly following cutting (Hinesley, 1988). The effect of colorant and needle sticker on the drying rate of redcedar is unknown. Thus, the objective of the current work was to examine several of these products in relation to postharvest drying and

Received for publication 26 Apr. 1989. I acknowledge the technical support of Layne Snelling and W.T. Huxster. The use of trade names in this publication does not imply endorsement by the NCARS of the products named, nor criticism of similar ones not mentioned. The cost of publishing this paper was defrayed in part by the payment of page charges. Under postal regulations, this paper therefore must be hereby marked advertisement solely to indicate this fact.

'Associate Professor. keeping quality of redcedar.

Eastern redcedar Christmas trees 1.5 to $2.0 \mathrm{~m}$ in height were used. Trees were growing $\approx 20 \mathrm{~km}$ southeast of Raleigh, N.C. Two products were tested (singly or in combination): 1) a representative latex-based, watersoluble pigment, Virginia Pinegreen, and 2) a liquid hydrostatic sticker, Needlehold (both, Kirk Co., Wautoma, Wise.). Table 1 lists the six treatments, which are similar to those that might be encountered in commercial Christmas tree operations. Each solution contained $3 \mathrm{ml}$ Triton AG-98 spreader activator/liter (Rohm and Haas, Philadelphia, Pa.) and $\mathrm{pH}$ was adjusted to $\approx 8.2$ with household ammonia (1 ml-liter $)^{-1}$. The ammonia was included because experience suggested that it improved the uniformity of surface coverage by Virginia Pinegreen. Materials were applied to standing trees between 1:00 PM and 3:00 PM on 11 Dec. 1987, using a backpack sprayer [pressure $=0.2$ to $0.3 \mathrm{MPa}$ (30 to 40 psi); nozzle $=8003$ LP flat spray tip (Spraying Systems, Wheaton, 111.)]. Each tree received $\approx 0.6$ liter of solution, which was enough to thoroughly wet visible portions of the crown. Ambient temperature was $13 \mathrm{C}$; relative humidity $60 \%$.

The 36 trees were harvested between 9:00 AM and 11:00 AM on 15 Dec. 1987. Temperature was $10 \mathrm{C}$, accompanied by fine mist and fog. Initial xylem water potential $(\psi)$ was measured with a pressure chamber (PMS Instruments, Corvallis, Ore.) and averaged - 0.3 to $-0.4 \mathrm{MPa}(\mathrm{n}=$ eight trees).

Trees were transported to Raleigh in a closed truck and stood upright in a 20C classroom. The room had fluorescent lighting between 8:00 AM and 10:00 PM daily. Relative humidity, which could not be controlled precisely, ranged from $30 \%$ to $70 \%$ during the 12-day experiment. When the water potential for an individual tree fell below - 5.0 $\mathrm{MPa}$ (2 to 3 days), a 5-cm-thick disk 